\title{
A Phosphorus Budget for the Lake Mendota Watershed
}

\author{
Elena M. Bennett, ${ }^{1 *}$ Tara Reed-A ndersen, ${ }^{1}$ Jeffrey N. Houser, ${ }^{1}$ \\ John R. Gabriel, ${ }^{2}$ and Stephen R. Carpenter ${ }^{1}$ \\ ${ }^{1}$ Center for Limnology, 680 North Park Street; and 2Department of Water Chemistry, \\ University of Wisconsin, Madison, Wisconsin 53706, USA
}

\begin{abstract}
A BSTRACT
A phosphorus $(\mathrm{P})$ budget was calculated for the agriculture-dominated Lake M endota watershed located in Dane and Columbia Counties, Wisconsin, USA. P inputs included fertilizer for agricultural crops and lawns, dietary supplements for dairy cattle, and natural inputs such as dry and wet deposition. Outputsincluded agricultural crops, livestock and livestock products, and hydrologic export to Lake Mendota. The total $\mathrm{P}$ input to the watershed $\left(1,307,000 \mathrm{~kg} \mathrm{year}^{-1}\right)$ and total output $(732,000 \mathrm{~kg}$ year $^{-1}$ ) are large relative to the average of $34,000 \mathrm{~kg}$ $P$ washing into the lake each year, indicating that the $P$ flux that eutrophies Lake Mendota is a very
\end{abstract}

\section{INTRODUCTION}

It is widely accepted that phosphorus (P) is a fundamental driver of lake primary production and that excessive $P$ input can degrade lakes through eutrophication (Vollenweider 1968; Schindler and others 1971; Dillon and Rigler 1974; EPA 1990a). Eutrophied lakes frequently experience noxious algal blooms, increased aquatic plant growth, and oxygen depletion, leading to degradation of their ecological, economic, and aesthetic value by restricting use for fisheries, drinking water, industry, and recreation (NRC 1992; Sharpley and others 1994). The detrimental effects of eutrophication havestimulated efforts to control $\mathrm{P}$ input to lakes.

Efforts to reduce point source $P$ pollution of lakes from sewage treatment plants and industrial sites

Received 31 August 1998; accepted 21 October 1998.

*Corresponding author; email: embennel@students.wisc.edu minor component of the total watershed $\mathrm{P}$ budget. Using the formula inputs - outputs = change in storage, we found that $575,000 \mathrm{~kg} \mathrm{P}$ accumulated in the watershed in 1995. This estimate was corroborated by long-term soil $P$ concentration data, which showed an average annual increase in soil P of over $450,000 \mathrm{~kg}$ year $^{-1}$. Future management programs designed to reduce $P$ inputs to Lake M endota will be compelled to cope with the large amount of $\mathrm{P}$ being stored in the watershed.

Key words: cultural eutrophication; eutrophication; phosphorus; watershed; lake; mass balance; land use.

have been largely successful since implementation of the Clean Water Act in 1972 (Sharpley and others 1994). However, non-point source P pollution remains a serious water quality problem (NRC 1992; Duda 1993). In many watersheds, agricultural activities, including application of excess fertilizer and manure to crop fields, are considered to be a major source of nonpoint P input to lakes (EPA 1990b, 1996; NRC 1992, 1993; Daniel and others 1994). In addition to degrading lakes, fertilizer lost as runoff represents a financial and energy loss both to society and to farmers.

Although the importance of studying nutrient cycling at the watershed scale has long been recognized (Bormann and Likens 1967; Likens 1974), the growing problem of nonpoint $P$ loading has increased the need for studies on this scale. Calculation of lake P budgets has advanced our understanding of in-lake $P$ dynamics, such as $P$ retention and recycling [for example, those summarized in Vollen- 
P Inputs

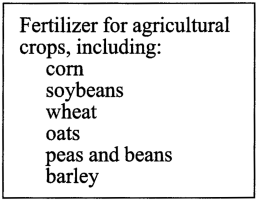

Feed supplements for dairy cattle

Fertilizer for urban lawn

Dry and wet deposition

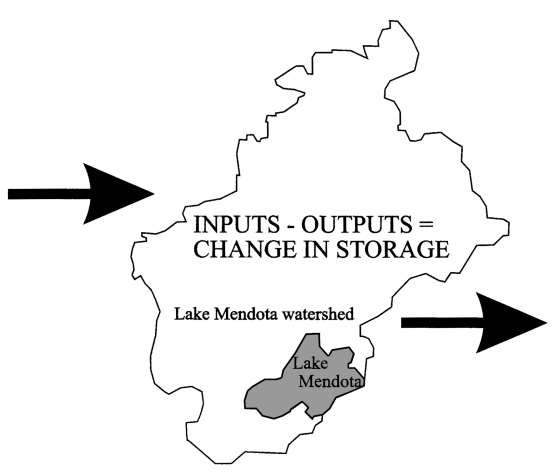

P Outputs

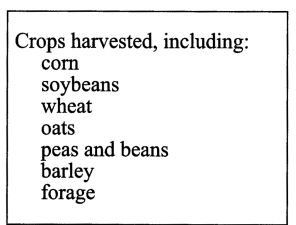

Animal products, including cattle hogs/pigs milk and dairy eggs

Hydrologic export to Lake Mendota
Figure 1. Schematic diagram of inputs and outputs used to calculate a phosphorus $(P)$ budget for the Lake Mendota watershed for 1995. weider (1968), Dillon (1975), Schindler and others (1976), and Campbell (1994)]. These studies contribute to lake restoration efforts that emphasize reduction of $P$ inputs, but they do not focus on the question of the magnitude of $P$ runoff relative to the $P$ budget of the entire watershed. Lowrance and colleagues (1985) showed that, in four subwatersheds of the Little River in the Georgia Coastal Plain, imports of P exceeded exports by 3.7-11.3 kg ha-1 year $^{-1}$. They concluded that a large percentage of the $P$ imported each year was being stored somewhere in the watershed. Similarly, in a nitrogen and $\mathrm{P}$ budget of the upper Potomac River Basin, Jaworski and coworkers (1992) found that over $60 \%$ of the imported $\mathrm{P}$ was retained within the watershed.

If $P$ inputs to a watershed exceed outputs, the excess P likely will be stored in the soil due to the propensity of phosphates to bind to soil particles. To our knowledge, however, there has been no attempt to link a watershed $P$ budget to the $\mathrm{P}$ content of the soil to examine this hypothesis. In Wisconsin, soil $\mathrm{P}$ budgets have shown that while $\mathrm{P}$ additions from commercial fertilizer have decreased since 1985, as much as $10 \mathrm{~kg} \mathrm{ha}^{-1}$ excess $\mathrm{P}$ is still added to the soil every year (Bundy 1994). Sharpley and others (1994) also found that inputs of $P$ in fertilizer and manure in excess of crop requirements have increased $P$ in the soil.

We calculated a P budget for the watershed of a eutrophic lake for which detailed $P$ budgets are known (Lathrop 1992; Soranno and others 1997; Lathrop and others 1998). We asked whether the $P$ runoff to the lake was a significant component of the terrestrial $\mathrm{P}$ budget. Budget estimates of $\mathrm{P}$ accretion in the watershed were compared with estimates of $P$ accretion in soils.

\section{Study Area}

The $686 \mathrm{~km}^{2}$ watershed of Lake Mendota is almost entirely contained within Dane County, Wisconsin, with a small portion in Columbia County. The upland soils are well-drained silt loams, whereasthe lowlands are poorly drained silts (Cline 1965). In 1995, the watershed land use was approximately $86 \%$ agricultural, 9\% urban, $4 \%$ wetlands, and $1 \%$ forest (Soranno and others 1996). The proportion of agricultural land had reached its current level by about 1870 (Lathrop 1992). Land use is currently changing through the conversion of agricultural land to urban uses (Dane County Regional Planning Commission 1992).

\section{Methods}

A mass-balance approach was used to calculate inputs, outputs, and change in storage (amount retained or lost by the watershed) of $\mathrm{P}$ in the Lake Mendota watershed for 1995. Jaworski and colleagues (1992) used a similar approach to evaluate the change in storage of nitrogen and $P$ for the Upper Potomac River Basin in Maryland, USA. Inputs of $P$ to the Mendota watershed are in the form of fertilizer for agricultural crops and urban lawns, feed supplements for dairy cattle, dry and wet deposition, groundwater flow, and weathering. $P$ leaves the watershed in corn and other crops, livestock and livestock products, and hydrologic export to Lake Mendota (Figure 1).

Inputs and outputs of $P$ were calculated based on values for 1995 from various published and unpublished sources (Table 1). The distribution of crops 
Table 1. Sources of Data Used to Calculate 1995 Phosphorus (P) Budget for the Lake Mendota Watershed

\begin{tabular}{|c|c|c|}
\hline Component & Subcomponent & Source \\
\hline \multicolumn{3}{|l|}{ Inputs } \\
\hline $\begin{array}{l}\text { Fertilizer for } \\
\text { agricultural crops }\end{array}$ & $\begin{array}{l}\text { Recommended fertilization rates } \\
\text { Typical rates of fertilization } \\
\text { Typical manure application rates } \\
\text { Amount of land planted in each crop }\end{array}$ & $\begin{array}{l}\text { Kelling and others } 1991 \\
\text { Nowak and others } 1996 \\
\text { P. Nowak, Rural Sociology, University of } \\
\text { Wisconsin, personal communication } \\
\text { DATCPa } 1996\end{array}$ \\
\hline $\begin{array}{l}\text { Feed supplements } \\
\text { for dairy cattle }\end{array}$ & $\begin{array}{l}\text { Recommended feed supplements for dairy cattle } \\
\text { Typical feed supplements for dairy cattle } \\
\text { Number of cattle in Dane County }\end{array}$ & $\begin{array}{l}\text { NRC } 1988 \\
\text { D. Undersander, Agronomy, University of } \\
\text { Wisconsin, personal communication } \\
\text { DATCP } 1996\end{array}$ \\
\hline $\begin{array}{l}\text { Fertilizer for urban } \\
\text { lawn }\end{array}$ & $\begin{array}{l}\text { Turf fertilization rates by homeowners } \\
\text { Turf fertilization rates by lawn care companies } \\
\text { Acreage of turf in the watershed } \\
\text { Percentage of homeowners using lawn care } \\
\text { services }\end{array}$ & $\begin{array}{l}\text { Pennsylvania Agricultural Statistics Service } \\
\text { Pennsylvania Agricultural Statistics Service } \\
\text { Bannerman and others } 1993 \\
\text { W. Kussow, Soil Science, University of Wisconsin, } \\
\text { personal communication }\end{array}$ \\
\hline $\begin{array}{l}\text { Atmospheric } \\
\text { deposition }\end{array}$ & $\begin{array}{l}\text { Dry deposition } \\
\text { Wet deposition }\end{array}$ & $\begin{array}{l}\text { Lathrop } 1979 \\
\text { Lathrop } 1979\end{array}$ \\
\hline \multicolumn{3}{|l|}{ Outputs } \\
\hline Crops harvested & $\begin{array}{l}\text { Amount of each crop harvested in Dane County } \\
\% \mathrm{P} \text { in each crop }\end{array}$ & $\begin{array}{l}\text { DATCP } 1996 \\
\text { NRC } 1982\end{array}$ \\
\hline Animal products & $\begin{array}{l}\text { Number of cattle and hogs in Wisconsin and } \\
\text { Dane County } \\
\text { Number of cattle and hogs slaughtered in } \\
\text { Wisconsin } \\
\text { \% P in cattle and hogs } \\
\text { Milk and eggs produced in Dane County } \\
\text { \% P in milk and eggs }\end{array}$ & $\begin{array}{l}\text { DATCP } 1996 \\
\text { DATCP } 1996 \\
\text { Georgievskii and others } 1982 \\
\text { DATCP } 1996 \\
\text { NRC } 1982\end{array}$ \\
\hline $\begin{array}{l}\text { Hydrologic export to } \\
\text { Lake Mendota }\end{array}$ & Hydrologic export to Lake Mendota & Lathrop and others 1998 \\
\hline
\end{tabular}

and livestock within the watershed was assumed to be proportional to the distribution in the county. Where numbers could not be obtained for the watershed, they were scaled down based on the ratio of watershed area to county area. Values for recommended fertilization rates (Kelling and others 1991), typical fertilization rates (Nowak and others 1996), and manure application rates (P. Nowak, Department of Rural Sociology, University of Wisconsin, personal communication), as well as the amount of land planted in each crop [Department of Agriculture, Trade, and Consumer Protection (DATCP) 1996] were used to calculate the amount of $\mathrm{P}$ imported as fertilizer for agriculture. Estimates of the amount of fertilizer applied by homeowners and professional lawn-care providers (Pennsylvania Agricultural Statistics Service n.d.), as well as an estimated percentage of homeowners who use professional lawn-care services (W. Kussow, personal communication) and the amount of turf in the urban part of the Lake Mendota watershed (Bannerman and others 1993), were used to calculate fertilizer imported for lawn care. All commercial fertilizer was considered to have been produced outside the watershed and imported. No P is mined within the watershed. All manure was considered to originate within the watershed. Information on feed supplement recommendations (NRC 1988), typical feed supplement use in Dane County (D. Undersander, Department of Agronomy, University of 
Wisconsin, personal communication), and number of cattle in the watershed (DATCP 1996) were used to calculate $\mathrm{P}$ imported in feed supplements for dairy cattle. Values for dry and wet deposition in the Madison area had been developed previously (Lathrop 1979).

Outputs were calculated in a manner similar to inputs. All products sold for human consumption were considered exports because they were either sold outside the watershed or the $\mathrm{P}$ they contained was removed through the sewage system. Since all sewage is released outside the watershed, all food produced for human consumption, including that consumed within the watershed, can be considered a single output. Amount and \%P of each product were used to determine $\mathrm{P}$ exported in agricultural crops, milk, and eggs (NRC 1982; DATCP 1996). The number of cattle and hogs were available for Dane County and were scaled down to the watershed (DATCP 1996). Rates of slaughter, available for the state and assumed to be similar to those for the county, were used to calculate the amount of P lost from the watershed through beef production (DATCP 1996). Percent $P$ in cattle and hogs was available from Georgievskii and colleagues (1982). Hydrologic export to Lake Mendota was based on 21 years of P-loading estimates for Lake Mendota (Lathrop and others 1998).

Retention of $\mathrm{P}$ was then calculated based on the formula

$$
\text { INPUTS }- \text { OUTPUTS }=\text { CHANGE-IN-STORAGE. }
$$

Uncertainties in the $\mathrm{P}$ budget were described by bracketing the most likely estimate with the minimum and maximum plausible values for each item. For inputs, uncertainties involved different assumptions about the amount of fertilizer applied to agricultural crops. The minimum calculation was based on the postulation that farmers apply commercial fertilizer in the amount recommended by the University of Wisconsin Extension (Kelling and others 1991). However, Nowak and coworkers (1996) showed that, in Dane County, farmers apply an average of $100 \mathrm{~kg} \mathrm{P} \mathrm{ha}^{-1}\left(91 \mathrm{lb} \mathrm{P}\right.$ acre ${ }^{-1}$ ) to fields planted in corn, whereas the amount recommended is only $50 \mathrm{~kg} \mathrm{P} \mathrm{ha}^{-1}\left(45 \mathrm{lb} \mathrm{P}\right.$ acre $\left.{ }^{-1}\right)$. The maximum calculation was based on the postulation that farmers apply approximately double the recommended rate of fertilizer to all crops. In the maximum estimate, all fertilizer used is commercial; that is, farmers do not credit manure application toward the amount of commercial fertilizer that they need to reach their intended level of fertilization. The most likely estimate is based on the assumption that farmers are crediting manure application and are therefore applying less commercial fertilizer ( $P$. Nowak personal communication). Bracketing for outputs was based on differences in the amount of forage exported versus that used or stored for future use within the watershed. The maximum output is based on export of $10 \%$ of all forage produced in the watershed. The most likely and minimum estimates are based on $5 \%$ and $0 \%$ export of all forage produced, respectively (D. Undersander personal communication).

Accumulation of $\mathrm{P}$ in the soil from 1974 to 1994 was based on available soil test $P$ data for Dane County averaged over 4-year periods (Combs and others 1996). These data were converted to $\mathrm{kg} \mathrm{P}$ year $^{-1}$ accumulation in the soil based on the average P-buffering capacity of soils in much of the United States: $3.632 \mathrm{~kg} \mathrm{P}$ acre ${ }^{-1}$ for every $1 \mu \mathrm{g} \mathrm{g}^{-1}$ increase in the Bray P-1 soil test (Leikam 1992).

\section{Results}

Estimates of total input of $\mathrm{P}$ to the Lake Mendota watershed ranged from a minimum of $851,000 \mathrm{~kg} \mathrm{P}$ year $^{-1}$ to a maximum of $1,717,000 \mathrm{~kg} \mathrm{P}$ year $^{-1}$. The most likely estimate was $1,307,000 \mathrm{~kg} P$ year ${ }^{-1}$ (Table 2A). Fertilizer for corn was the largest single source of $\mathrm{P}$, accounting for $54.3 \%$ of all $\mathrm{P}$ entering the watershed (most likely estimate). The secondlargest input of $\mathrm{P}$ to the watershed was feed supplements for dairy cattle, accounting for $18.2 \%$ of inputs. $P$ input as corn fertilizer were the least precise components of the budget, with a range that was nearly $75 \%$ of the nominal estimate. Natural movement of $\mathrm{P}$ into the watershed, through dry and wet deposition, makes up only a small percentage $(4.7 \%)$ of the total inputs in this budget. Humaninduced movement of $P$, through the import of fertilizer and feed supplements, comprises the majority of the budget (95.3\%).

Estimates of $\mathrm{P}$ lost from the watershed range from a minimum of $729,000 \mathrm{kgP}_{\text {year }}-1$ to a maximum of $735,000 \mathrm{~kg} \mathrm{P}$ year $^{-1}$. The most likely estimate is an output of $732,000 \mathrm{~kg} \mathrm{P}$ year ${ }^{-1}$ (Table 2B). Corn exported was the largest source of $P$ lost from the watershed, accounting for $55.3 \%$ of all outputs. The second-largest output item was dairy products, which accounted for $10.5 \%$ of the total output. The only item that differed in the minimum and maximum estimates was forage, which ranged from 0 to $6200 \mathrm{~kg} \mathrm{P}$ year $^{-1}$ exported. Natural export of P, through hydrologic export to Lake Mendota, made up only $4.6 \%$ of the total outputs. Human-caused 
Table 2A. Most Likely, Minimum, and Maximum Estimates of Phosphorus (P) Inputs to the Lake Mendota Watershed in $\mathrm{kg} \mathrm{P}$ year $^{-1}$ a

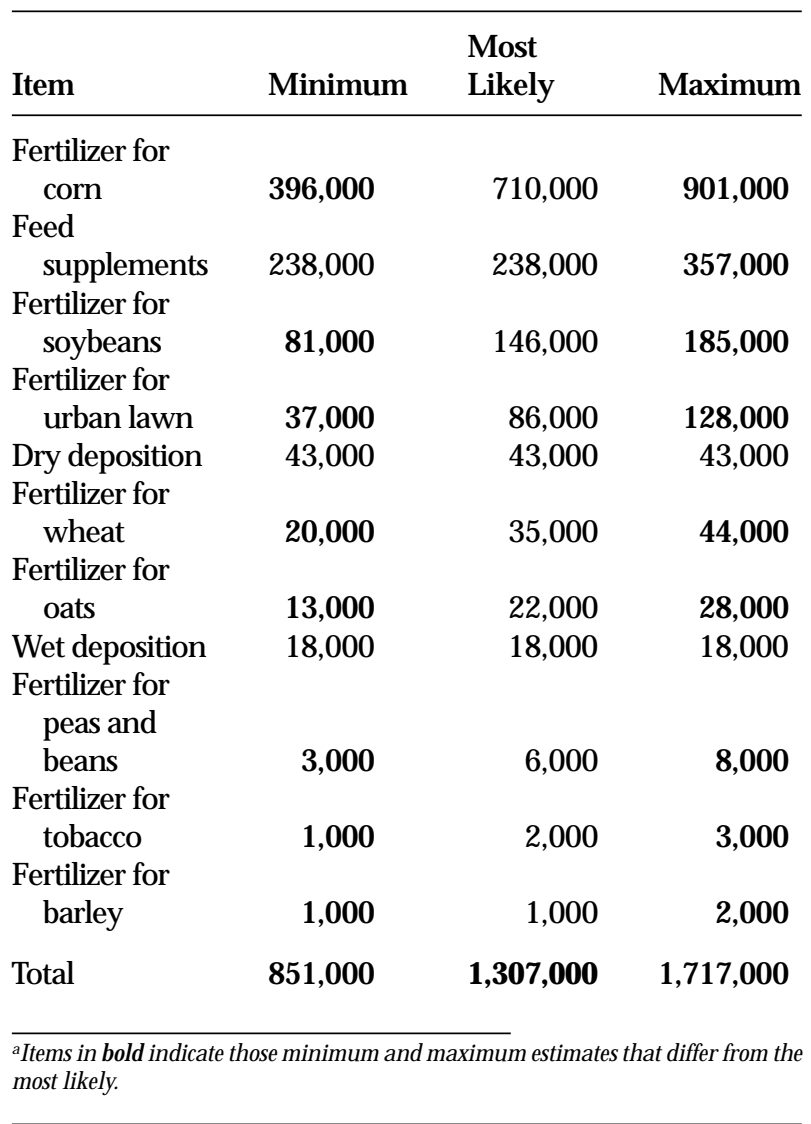

movement of $\mathrm{P}$ was responsible for $95.4 \%$ of all $\mathrm{P}$ leaving the watershed.

There was considerably more uncertainty in the inputs than in the outputs. Uncertainty associated with inputs is due to the difficulty of estimating how much commercial fertilizer and manure is applied by farmers. Variability in fertilization practices is high, and average farmer behavior may be misleading (Nowak and others 1996). Variation in P output reflects uncertainty in the amount of forage exported from the watershed versus that consumed by animals or stored for future use within the watershed.

The most likely estimates of $\mathrm{P}$ budget for the Lake Mendota watershed clearly show that the amount of $\mathrm{P}$ entering the watershed $\left(1,307,000 \mathrm{~kg} \mathrm{P}^{\mathrm{P}}\right.$ year $\left.{ }^{-1}\right)$ exceeds the amount of $\mathrm{P}$ lost from the watershed $\left(732,000 \mathrm{kgP}\right.$ year $\left.{ }^{-1}\right)$. Nearly half the P entering the watershed is retained.

Changes in the soil P levels in Dane County over the past 20 years corroborate this result (Figure 2). Soil tests in Dane County indicate that $\mathrm{P}$ in the soil
Table 2B. Most Likely, Minimum, and Maximum Estimates of P Outputs from the Lake Mendota Watershed in $\mathrm{kg} \mathrm{P}$ year $^{-1}$

\begin{tabular}{|c|c|c|c|}
\hline Item & Minimum & $\begin{array}{l}\text { Most } \\
\text { Likely }\end{array}$ & Maximum \\
\hline Corn & 405,000 & 405,000 & 405,000 \\
\hline Dairy products & 77,000 & 77,000 & 77,000 \\
\hline Eggs & 73,000 & 73,000 & 73,000 \\
\hline Soybeans & 70,000 & 70,000 & 70,000 \\
\hline Cattle & 42,000 & 42,000 & 42,000 \\
\hline \multicolumn{4}{|l|}{ Export to Lake } \\
\hline Mendota & 34,000 & 34,000 & 34,000 \\
\hline Wheat & 10,000 & 10,000 & 10,000 \\
\hline Peas and beans & 8,000 & 8,000 & 8,000 \\
\hline Oats & 5,000 & 5,000 & 5,000 \\
\hline Hogs and pigs & 4,000 & 4,000 & 4,000 \\
\hline Forage & 0 & 3,000 & 6,000 \\
\hline \multicolumn{4}{|l|}{ Barley and } \\
\hline tobacco & 1,000 & 1,000 & 1,000 \\
\hline Total & 729,000 & 732,000 & 735,000 \\
\hline
\end{tabular}

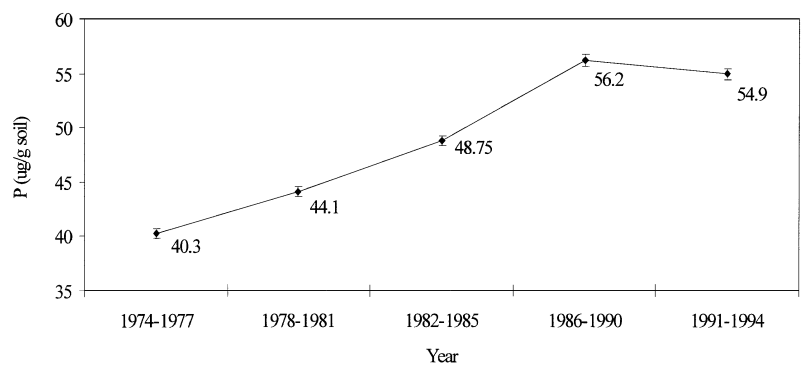

Figure 2. Soil test phosphorus $(\mathrm{P})$ data for Dane County (1974-94), with 95\% confidence intervals (Combs and others 1996).

has increased annually by approximately 450,000 $\mathrm{kg} \mathrm{P}$ year $^{-1}$ (Combs and others 1996), which agrees reasonably with the retention of $575,000 \mathrm{~kg} P$ year $^{-1}$, as determined by excess input in the $\mathrm{P}$ budget for 1995.

\section{Discussion}

The $1995 \mathrm{P}$ budget for the Lake M endota watershed clearly shows that the amount of $\mathrm{P}$ that enters the watershed exceeds the output, indicating that $P$ is being retained in the watershed. Changes in soil test $P$ levels in Dane County confirm this excess and indicate that the surplus $\mathrm{P}$ is being stored in the soil. Correspondence of these results indicates that the general argument is unlikely to be changed qualitatively by quantitative refinements. Excess imports 
of $\mathrm{P}$, derived from fertilizers and feed, are accumulating in the soils of the Lake Mendota watershed.

Allowing soil P levels in the Lake Mendota watershed to drop could take many years. If we were to stop overfertilizing immediately and apply only as much $P$ as leaves the watershed in agricultural products each year (assuming that agricultural production, and therefore export of $\mathrm{P}$, will not decrease with reduced fertilization), it would take over 260 years for $P$ in the soil to drop to 1974 levels. Calculations based on the additional movement of $P$ through the watershed that is caused by human actions show that even if we were to cease importing P to the watershed completely, it would still take at least 12 years for the $P$ in the soil to drop to 1974 levels.

In the absence of a reduction in $P$ fertilizer usage, the $P$ accumulating in the watershed will wash downhill and contribute to eutrophication of the lake. Chemicals such as $\mathrm{P}$ that appear to be sequestered in the soil may later be mobilized by a geologic, hydrologic, chemical, or climatic event such acid precipitation or heavy summer thunderstorms. $\mathrm{P}$ could also be mobilized by changes in land-management practices or some unpredictable mechanism. In this sense, $P$ accumulation in the watershed can be viewed as what Stigliani and others (1991) term a "chemical time bomb" in the soil. Future management programs designed to reduce $P$ input to Lake Mendota will have to take into account the excess $P$ being stored in the watershed soil. Although not all of the accumulated $P$ will reach Lake Mendota, not very much of it has to in order to maintain the eutrophic state of the lake (Lathrop and others 1998). Our results indicate that the eutrophication of Lake Mendota is caused by only a small percentage of the P moving through the watershed.

The general pattern of $\mathrm{P}$ accumulation seen in the Lake Mendota watershed is not an issue restricted to this watershed. Global P cycle data show that, on average, $\mathrm{P}$ is building up in the world's soil (Carpenter and others 1998). P inputs to the world's oceans are also increasing (Howarth and others 1995). Howarth and colleagues (1995) attribute $70 \%$ of this increase to increased erosion and the remaining $30 \%$ to increased $\mathrm{P}$ stored in the world's soils. P accretion in agricultural soil has been documented at a national scale. In the United States and Europe, only about $30 \%$ of $\mathrm{P}$ input in fertilizers is exported in agricultural products (Isermann 1991; NRC 1993). This pattern has also been documented at the watershed scale [for example, see Lowrance and others (1985) and Jaworski and others (1992)]. Fluck and others (1992) found that less than $20 \%$ of the $\mathrm{P}$ input to the Lake Okeechobee watershed is output in agricultural and other products. At many scales, including global, national, regional, and local, $P$ has been shown to be accumulating in agricultural soils.

Accumulation of $P$ in the soils of the world's agricultural watersheds could lead to an increase in the number of eutrophied lakes worldwide and a decrease in the social, economic, and ecological value of these lakes (Postel and Carpenter 1997). Decreases in water quality reduce the amount of water available for human use, or increase the costs of purifying water, and thereby contribute to problems of dwindling water supplies (Postel 1997). Management efforts to reduce $P$ inputs to lakes worldwide will be compelled to cope with increased amounts of $\mathrm{P}$ stored in watershed soils.

\section{ACKNOWLEDGM ENTS}

We thank Peter Nowak and Richard Bishop, professors of the University of Wisconsin course for which this article was originally written, for their helpful feedback on early versions of this research. This article benefited from the hel pful comments of J eff Cardille, Ben Greenfield, Tim Essington, and Dick Lathrop. Weare indebted to the following people for their help in providing us with the wide variety of data and data sources necessary to complete this research: Roger Bannerman, Larry Bundy, Mike Koran, Wayne Kussow, Dick Lathrop, Richard Proost, Aicardo Roa-Espinosa, Jim Schmid, Ron Tauchen, and Dan Undersander. This work was supported by the Pew Foundation and the National Science Foundation.

\section{REFERENCES}

Bannerman RT, Owens DW, Dodds RB, Hornewer NJ. 1993. Sources of pollutants in Wisconsin stormwater. Wat Sci Technol 28:241-59.

Bormann FH, Likens GE. 1967. Nutrient cycling. Science 155: 424-9.

Bundy LG. 1994. Trends in the phosphorus balance in Wisconsin. Available from: Department of Agriculture, Trade, and Consumer Protection (DATCP), Madison, Wisconsin; $9 \mathrm{p}$.

Campbell P. 1994. Phosphorus budgets and stoichiometry during the open water season in two unmanipulated lakes in the Experimental Lakes Area, Northwestern Ontario. Can J Fish Aquat Sci 51:2739-55.

Carpenter SR, Caraco NF, Correll DL, Howarth RW, Sharpley AN, Smith VH. 1998. Nonpoint pollution of surface waters with phosphorus and nitrogen. Ecol Appl 8:559-68.

Cline DR. 1965. Geology and groundwater resources of Dane County, Wisconsin. Washington (DC): US Geological Survey; Water Supply Paper nr 1779.

Combs SM, Bullington SW, Herring H. 1996. Twenty years of Wisconsin soil testing, 1974-1994. Available from: Department 
of Soil Science, University of Wisconsin, Madison, Wisconsin; New Horizons in Soil Science nr 9-96; $26 \mathrm{p}$.

Dane County Regional Planning Commission. 1992. Regional trends: Dane County, Wisconsin 1991. Available from: Dane County Regional Planning Commission, Madison, Wisconsin.

Daniel TC, Sharpley AN, Edwards DR, Wedepohl R, Lemunyon JL. 1994. Minimizing surface water eutrophication from agriculture by phosphorus management. J Soil Wat Conserv 49:30-38.

Department of Agriculture, Trade, and Consumer Protection. 1996. Wisconsin Agricultural Statistics-1995. Madison (WI): Wisconsin Agricultural Statistics Service.

Dillon PJ. 1975. The phosphorus budget of Cameron Lake, Ontario: the importance of flushing rate to the degree of eutrophy of lakes. Limnol Oceanogr 20:28-39.

Dillon PJ , Rigler FH. 1974. The phosphorus-chlorophyll relationship in lakes. Limnol Oceanogr 19:767-73.

Duda AM. 1993. Addressing nonpoint sources of water pollution must become an international priority. Wat Sci Technol 28: 1-11.

[EPA] US Environmental Protection Agency. 1990a. The lake and reservoir restoration guidance manual. Washington (DC): USEPA; EPA-440/5-88-02.

[EPA] US Environmental Protection Agency. 1990b. National water quality inventory: 1988 report to congress. Washington (DC): Office of water criteria and standards division, US Government Printing Office.

[EPA] US Environmental Protection Agency. 1996. Environmental indicators of water quality in the United States. Washington (DC): USEPA, Office of Water Criteria and Standards Division (4503F), US Government Printing Office; EPA 841-R-96-002; $25 \mathrm{p}$.

Fluck RC, Fonyo C, Flaig E. 1992. Land-use-based phosphorus blanaces for Lake Okeechobee, Florida, drainage basins. Applied Engineering in Agriculture 8:813-20.

Georgievskii VI, Annenkov BN, Samokhin VI. 1982. Mineral nutrition of animals. London: Butterworths.

Howarth RW, J enson HS, Marino R, Postma H. 1995. Transport to and processing of $\mathrm{P}$ in near-shore oceanic waters. In: Tiessen, editor. Phosphorus in the global environment. New York: J ohn Wiley and Sons. p 323-45

Isermann K. 1991. Share of agriculture in nitrogen and phosphorus emissions into the surface waters of Western Europe against the background of their eutrophication. Fert Res 26:253-69.

Jaworski NA, Groffman PM, Keller AA, Prager JC. 1992. A watershed nitrogen and phosphorus balance: the upper Potomac River basin. Estuaries 15:83-95.

Kelling KA, Schulte EE, Bundy LG, Combs SM, Peters JB. 1991. Soil test recommendations for field, vegetable, and fruit crops. Available from: University of Wisconsin Extension, Madison, Wisconsin; Publication A2809.

Lathrop RC. 1979. Appendix H: lake management. In: Dane County water quality plan, volume 2. Madison (WI): Dane County Regional Planning Commission. p H1-77.

Lathrop RC. 1992. Nutrient loadings, lake nutrients, and water clarity. In: Kitchell JF, editor. Food web management: a case study of Lake Mendota. New York: Springer-Verlag. p 69-96.

Lathrop RC, Carpenter SR, Stow CA, Soranno PA, Panuska JC. 1998. Phosphorus loading reductions needed to control blue- green algal blooms in Lake Mendota. Can J Fish Aquat Sci 55:1169-78.

Leikam DF. 1992. Summary of phosphorus fertilizer use effects on soil test phosphorus. In: Proceedings of the North Central Extension-Industry Soil Fertility Workshop 8:108-117.

Likens GE. 1974. Linkages between terrestrial and aquatic ecosystems. BioScience 24:447-56.

Lowrance RR, Leonard RA, Asmussen LE, Todd RL. 1985. Nutrient budgets for agricultural watersheds in the southeastern coastal plain. Ecology 66:287-96.

Nowak P, Shepard S, Weiland C. 1996. Utilizing a needs assessment in water quality program implementation for the Lake Mendota watershed: the farm practices inventory (FPI) report \#2. Available from: Environmental Resources Center, University of Wisconsin.

[NRC] National Research Council. 1982. United States-Canadian tables of feed composition. Washington (DC): National Academy Press.

[NRC] National Research Council. 1988. Nutrient requirements of dairy cattle. Washington (DC): National Academy Press.

[NRC] National Research Council. 1992. Restoration of aquatic ecosystems: science, technology, and public policy. Washington (DC): National Academy Press.

[NRC] National Research Council. 1993. Soil and water quality: an agenda for agriculture. Washington (DC): National Academy Press.

Pennsylvania Agricultural Statistics Service. [No publication date.] Pennsylvania turfgrass survey-1989. Available from: Pennsylvania Department of Agriculture, 2301 North Cameron Street, Harrisburg, PA 17110-9408.

Peterjohn WT, Correll DL. 1984. Nutrient dynamics in an agricultural watershed: observations on the role of a riparian forest. Ecology 65:1466-75.

Postel SL. 1997. Last oasis. 2nd ed. Washington (DC): Island.

Postel SL, Carpenter SR. 1997. Freshwater ecosystem services. In: Daily GC, editor. Nature's services. Washington (DC): Island. p 195-213.

Schindler DW, Armstrong FAJ , Holmgren SK, Brunskill GJ . 1971. Eutrophication of lake 227, Experimental Lakes Area, northwestern Ontario, by addition of phosphate and nitrate. J Fish Res Board Can 28:2009-36.

Schindler DW, Newbury RW, Beaty KG, Campbell P. 1976. Natural water and chemical budgets for a small Precambrian lake basin in central Canada. J Fish ResBoard Can 33:2526-43.

Sharpley AN, Chapra SC, WedepohI R, SimsJ T, Daniel TC, Reddy KR. 1994. Managing agricultural phosphorus for protection of surface waters: issues and options. J Environ Qual 23:437-51.

Soranno PA, Carpenter SR, Lathrop RC. 1997. Internal phosphorus loading in Lake Mendota: response to external loads and weather. Can J Fish Aquat Sci 54:1883-93.

Soranno PA, Hubler SL, Carpenter SR, Lathrop RC. 1996. Phosphorus loads to surface waters: a simple model to account for the spatial pattern of land use. Ecol Appl 6:865-78.

Stigliani WM, Doelman P, Salomons W, Schulin R, Smidt GRB, Van der Zee SEATM. 1991. Chemical time bombs: predicting the unpredictable. Environment 33:4-30.

Vollenweider RA. 1968. The scientific basis of lake and stream eutrophication with particular reference to phosphorus and nitrogen as eutrophication factors. Paris: OECD; Technical Report DAS/C81/68; 27:1-182. 